\title{
Propagation Techniques for a Spineless Acacia wrightii
}

\author{
Donita L. Bryan, ${ }^{1}$ Michael A. Arnold, ${ }^{2}$ R. Daniel Lineberger, ${ }^{2}$ and \\ W. Todd Watson ${ }^{4}$ \\ Department of Horticultural Sciences, Texas A \& M University, MS 2133, \\ College Station, TX 77843-2133
}

Additional index words. Acacia wrightii, wright's acacia, grafting, tissue culture, rooted cuttings, scarification

\begin{abstract}
Three spineless phenotypes of Acacia wrightii G. Bentham ex A. Gray were identified with aesthetic landscape potential. Experiments in seed, cutting, grafting, and tissue culture propagation were undertaken to perpetuate this desired spineless phenotype. Germination percentages for mechanically scarified seeds ranged from $33 \%$ to $94 \%$, however yield of spineless seedlings was low (0\% to 34\%). Sulfuric acid scarification for 10 , 20,30, or 60 minutes hastened and unified germination compared to nontreated seeds by 7 to 8 days. Vegetative propagation was successful for softwood cuttings. Rooting measures increased with auxin $(2: 1$ indole butyric acid to naphthalene acetic acid) concentrations from 0 to $15000 \mathrm{mg} \cdot \mathrm{L}^{-1}$, with maximum rooting percentage $(70 \%)$, root number $(9.2)$, and root length $(12.4 \mathrm{~cm})$ per softwood cutting at $15000 \mathrm{mg} \cdot \mathrm{L}^{-1}$ auxin 8 weeks after treatment. Rooting was not successful for semi-hardwood or hardwood cuttings. Whip-and-tongue or T-bud grafting was not successful. Tissue culture of shoots from in vitro germinated seedlings indicated that shoot proliferation was greatest in Murashige and Skoog (MS) medium with $15 \mu \mathrm{M}$ zeatin. The number of shoots that rooted in vitro increased with increasing concentrations of indole-3-butyric acid from 0 to $25 \mu \mathrm{M}$.
\end{abstract}

In the southwestern U.S., the infertile, alkaline soils and harsh, hot, dry climate create a landscaping challenge. Acacia spp. have many attributes which contribute to their successful use in landscapes as cultivated trees. They have ornamental value (McWilliam, 1987), can adapt to extremes of temperature, moisture, and stress (Vengadesan et al., 2002), and can be grown in different site conditions including acidic to alkaline, infertile, saline, and arid soils (McWilliam, 1987). Many drought adapted Acacia spp. have spines, formed from stipules at the base of a compound leaf. This characteristic may constitute a maintenance liability or a pedestrian hazard or both (Arnold, 2002), and therefore a spineless Acacia spp. would be more desirable for landscape use.

A genetic variant of Acacia wrightii G. Bentham ex A. Gray was found with a spineless phenotype (Arnold, 2002). Acacia wrightii has small, semi-evergreen to deciduous, bipinnately compound leaves and attractive white

Received for publication $22 \mathrm{Feb} .2005$. Accepted for publication 9 Apr. 2005. This study was included as part of a thesis written in partial fulfillment of the requirements for the MS degree by D.L. Bryan. The authors wish to thank the Microscopy and Imaging Center and Rick Littleton for the ESEM (NSF Grant No. ECS-9214314) photographs. Mention of a trademark, proprietary product, or vendor does not constitute a guarantee or warranty of the product by the authors or the Texas A\&MUniversity and does not imply its approval to the exclusion of other products or vendors that also may be suitable.

${ }^{1}$ Graduate student.

${ }^{2}$ Professor.

${ }^{3}$ Assistant professor, Department of Forest Science, Texas A\&M University, MS 2135, College Station, TX 77843-2135. to yellow-white cylindrical flowers with peak blooming in spring and occasional flowering throughout its growth period (Arnold, 2002; Nokes, 2001).

In order for spineless selections of $A$. wrightii to be commercially viable in nursery production systems, a reliable, efficient, and true-to-type propagation method must be determined. Preliminary results exploring some potential strategies were published in an extended abstract (Bryan et al., 2002). The present paper confirms these responses in detail, as well as adding the proliferation, in vitro rooting and micrograph work. The objective of this research was to define potential commercially acceptable propagation methods (seed, cuttings, grafting, or tissue culture) to perpetuate the desired spineless trait of the $A$. wrightii selections.

\section{Materials and Methods}

Maintenance of spineless trait from seeds. Seeds were collected from three spineless $A$. wrightii (designated selections A, B, and C) located in the landscape at the Texas A\&MUniversity Horticultural Gardens in College Station, Texas (lat. $30^{\circ} 60^{\prime} 44^{\prime} \mathrm{N}$ long. 96 $36^{\circ} 1^{\prime} 22^{\prime} \mathrm{W}$ ). Seeds were collected in the summers of 1999 through 2002 from the A. wrightii spineless selections with the exception of selection $\mathrm{C}$, which died in the winter of 2001. Seeds were dried at ambient atmospheric temperatures (on the tree) and then stored in brown paper bags at $5^{\circ} \mathrm{C}$.

In August 1999, 69 seeds from selection A, 17 from selection $B$, and 290 from selection $\mathrm{C}$ (maximum number of seeds available from each selection) were planted to test germina- tion and yield of spineless seedlings. Seeds of each selection were mechanically scarified after being removed from the pods by cutting a notch in the seedcoat with manual, double blade, pruning shears (Lisam, Imola, Italy). Seeds were then planted in $38 \times 53 \times 10 \mathrm{~cm}$ black plastic flats (Kadon Corp., Dayton, Ohio) containing moistened substrate. The substrate was composed of $60 \%$ pine bark, $20 \%$ peat, $10 \%$ vermiculite, and $10 \%$ haydite clay containing $0.3 \mathrm{~g}$ of Peters professional water-soluble fertilizer $15 \mathrm{~N}-2.2 \mathrm{P}-12.5 \mathrm{~K}$ (Scotts-Sierra Horticultural Products Co., Marysville, Ohio) per cubic meter. Flats were placed on benches in a container nursery under $55 \%$ light exclusion in College Station, Texas. Germination was recorded after 2 weeks.

After assessing germination, seedlings were transferred to $2.1 \mathrm{~L}$ containers (Nursery Supplies Inc., Fairless Hills, Pa.) when they reached a height of about $7 \mathrm{~cm}$. Containers were then placed on gravel nursery beds. Plants were fertigated with sulfuric acid injected water $(\mathrm{pH}$ 6.3 to 6.5 ) containing $50 \mathrm{mg} \cdot \mathrm{L}^{-1}$ of $\mathrm{N}$ from a water soluble fertilizer (Peters professional acid special, 21N-3.1P-5.8K, Scott's Co., Marysville, Ohio) at $0.27 \mathrm{~L} \cdot \mathrm{min}^{-1}$ for $5 \mathrm{~min}$ on a daily basis for the duration of the experiment (excluding 1 Nov. to 1 Feb.) using one spray stake per container (aboveground $12 \mathrm{~cm}$ Spot-Spitter, SS-AG160LGN-100, Roberts Irrigation, San Marcos, Calif.) with a $160^{\circ}$ spray pattern. Each container was fertilized with 28.4 $\mathrm{g}$ of $18 \mathrm{~N}-3.1 \mathrm{P}-8.3 \mathrm{~K}$ Osmocote (Scotts Co.) every 3 months during the growing season. At 7 and 10 months after transplanting, plants were observed to confirm the spineless phenotype. These 1999 seedlings were later used as the rootstocks for the grafting studies. In May 2001, seed propagation of spineless phenotypes was repeated using selections A (10 seeds), B (42), and $C$ (102). Spineless phenotypes from these seedlings were determined at transplanting.

Sulfuric acid and mechanical scarification. Seeds collected from selection $\mathrm{C}$ in summer 2000 were used for the sulfuric acid and mechanical scarification experiments. The first experiment began on 19 July 2002, and the second experiment began on 31 Oct. 2002. Both experiments were conducted for $17 \mathrm{~d}$. Treatments for the first experiment were 0,30 , 60,90 , or 120 min in concentrated sulfuric acid (H2SO4) (Assay 95.0\% to 98.0\%, EM Science, Gibbstown, N.J.), or mechanical scarification. Seedcoats for mechanical scarification were notched with manual, double blade, pruning shears (Lisam, Imola, Italy). Treatments for the second experiment were $0,10,20,30$, or 60 min in concentrated sulfuric acid or mechanical scarification. Five replications of 20 seeds per treatment were used in each experiment. Seeds were placed in beakers containing 50 $\mathrm{mL}$ concentrated sulfuric acid and after the designated times they were rinsed under running tap water for $1 \mathrm{~min}$.

Seeds were placed in petri dishes (Curtin Matheson Sci. Inc., Houston, Texas) containing water agar $\left(6 \mathrm{~g} \cdot \mathrm{L}^{-1}\right)$ made from Phytagar (Gibco Laboratories, Grand Island, N.Y.). Dishes were then placed in a growth chamber (modelQ4834; Environmental Growth Cham- 
bers, Chagrin Falls, Ohio) set at $25^{\circ} \mathrm{C} / 20^{\circ} \mathrm{C}$ day/night temperature. Daylength was for $12 \mathrm{~h}$ with light levels of $290 \mu \mathrm{mol} \cdot \mathrm{m}^{-2} \cdot \mathrm{s}^{-1}$ measured at bench height with a quantum meter (Model QMSW, Apogee Instruments Inc., Logan, Utah). Seeds were monitored for germination (emergence of the radicle) every $12 \mathrm{~h}$ for $2 \mathrm{~d}$, and then once a day for the remaining $17 \mathrm{~d}$.

The experimental design was completely randomized, consisting of 5 replications of 20 seeds each. Statistical analysis of experiments was performed using the general linear models procedures in SAS Systems for Windows, Release 6.12 (SAS Institute Inc., Cary, N.C.) to determine effects of acid and mechanical treatments over time. Asquare root transformation was performed on percent germination data before analysis to achieve a more normalized distribution. Sigmoidal regression equations were calculated and presented where significant $(P \leq 0.01)$.

Propagation of cuttings. Acacia wrightii spineless selection $\mathrm{C}$ was used as the stock plant. Cuttings included the shoot apex and were about $7 \mathrm{~cm}$ in length. Hardwood, softwood, and semi-hardwood stages were taken on 18 Feb., 21 May, and 30 Sept. 2001, respectively. The basal $1 \mathrm{~cm}$ of the cuttings was dipped for $5 \mathrm{~s}$ in a solution containing a commercial rooting hormone (Dip 'n Grow, Astoria-Pacific, Inc., Clackamas, Ore.), which contained $1.0 \%\left(10000 \mathrm{mg} \cdot \mathrm{L}^{-1}\right)$ indole-3butyric acid (IBA) and $0.5 \%\left(5000 \mathrm{mg} \cdot \mathrm{L}^{-1}\right)$ 1-napthaleneacetic acid (NAA). Treatments were formulated at $0,5000,10000$, or 15000 $\mathrm{mg} \cdot \mathrm{L}^{-1}$ of total auxin in an aqueous solution. Three replications per cutting stage were used with 10 cuttings per treatment per replication (120 total cuttings per growth stage). Cuttings were placed in black plastic flats containing a pine bark substrate composed of $0.76 \mathrm{~m}^{3}$ of pine bark mulch (screened to $1.5 \mathrm{~cm}$ ) amended with $7 \mathrm{~kg}$ Osmocote $(18 \mathrm{~N}-3.1 \mathrm{P}-8.3 \mathrm{~K}$, Scotts Co.), $4 \mathrm{~kg}$ dolomitic limestone (Austin White Lime Company, Austin, Texas), 2 kg gypsum (The Earl Ricketts Co., Tampa, Fla.), and $1 \mathrm{~kg}$ Micromax (The Scotts Co.) per cubic meter. Flats were then placed under mist (6s of mist every $10 \mathrm{~min}$; dawn to dusk), under ambient greenhouse conditions (day/night $26.7^{\circ} \mathrm{C} / 26.1$ ${ }^{\circ} \mathrm{C}$, model STEP 50A; Wadsworth Control Systems, Inc., Arvada, Colo.) at College Station, Texas.

Softwood, semi-hardwood, and hardwood cuttings were harvested at 8,9 , and 10 weeks after rooting hormone treatment, respectively. Harvest dates varied between cutting types depending on root establishment and overall health of cuttings. Cuttings were removed from the flats and the roots were washed. Data collected included cutting mortality, presence of callus, root formation, root number per cutting, and root length.

The experimental design was a randomized complete block design, with three blocks of 10 cuttings per auxin treatment $(0,5000,10000$, or $\left.15000 \mathrm{mg} \cdot \mathrm{L}^{-1}\right)$ nested within each cutting stage (softwood, semi-hardwood and hardwood). An analysis of variance was performed using the general linear models procedure in SAS Systems for Windows, Release 6.12
(SAS Institute Inc., Cary, N.C.) to determine whether there were interactions among stages of cuttings taken and auxin concentrations for number of cuttings rooted, number of roots regenerated per cutting, and total root length per cutting. Linear and polynomial regression equations were calculated where significant $(P \leq 0.05)$.

Grafting. Scions from selection C were collected in April 2001 and grafted using whip-and-tongue and T-budding grafting methods (Garner, 1993) onto seedling rootstocks. Twenty whip-and-tongue grafts were made on seedling rootstocks from selection $\mathrm{C}$ and 20 on selections A and B seedlings combined. Another 20 whip-and-tongue grafts were made on selection C rootstocks with an $8000 \mathrm{mg} \cdot \mathrm{L}^{-1}$ auxin (IBA) in talcum powder (Hormex \#3, Brooker Chemical Corp., Chatsworth, Calif.) applied to the graft. Twenty T-buds were grafted onto rootstocks from selection $\mathrm{C}$ and 20 from $\mathrm{A}$ and $\mathrm{B}$ rootstocks combined. Grafts were wrapped with Parafilm (American National Can, Greenwhich, Conn.) and placed in a container nursery as previously described, but under $55 \%$ light exclusion. A total of 100 grafts were performed.After 4 weeks, the grafts were examined for callus formation.

Tissue culture and shoot proliferation. In experiment 1 , seeds collected in October 2000 from $A$. wrightii thornless selection $\mathrm{C}$ were soaked in $200 \mathrm{~mL}$ sulfuric acid in August 2001 for 30 min with occasional stirring. Seeds were rinsed with water and wrapped in cheesecloth before immersion in a continuously stirred $1.6 \%$ sodium hypochlorite solution(Federated Group, Inc., Arlington Heights, Ill.) (Douglas, 1995) containing $0.5 \%$ Tween 80 (Fisher Scientific, Fair Lawn, N.J.) for $30 \mathrm{~min}$. Seeds were then rinsed three times in sterile autoclaved water in a laminar flow hood (model EG-5252; The Baker Co., Inc., Sanford, Maine). Seeds were then placed on $0.6 \%$ water agar (Phytagar) under sterile conditions. Cultures were grown under 16-h photoperiods from fluorescent lighting at $16 \mu \mathrm{mol} \cdot \mathrm{m}^{-2} \cdot \mathrm{s}^{-1}$ measured at bench height. Germinated seeds were transferred after $19 \mathrm{~d}$. Shoot tips from germinated seedlings were excised and cultured on Murashige and Skoog (MS) (Murashige and Skoog, 1962) or Woody Plant Medium (WPM) (Lloyd and McCown, 1980). Agar $\left(6 \mathrm{~g} \cdot \mathrm{L}^{-1}\right)$ and sucrose $\left(30 \mathrm{~g} \cdot \mathrm{L}^{-1}\right)$ were added to both MS and WPM. The growth regulators benzyladenine (BA) (Sigma Chemical Co., St. Louis, Mo.) and zeatin (Z) (zeatin: mixed isomers, Phytotechnology Laboratory, Shawnee Mission, Kans.) were compared in each medium at $0,5,10,15$, or $20 \mu \mathrm{M}$. Four replications of four shoots per treatment were used ( 16 shoots per treatment).

Explants were evaluated 8 weeks after transfer by observing mortality, contamination, callus formation, and shoot proliferation. An evaluation scale was used to determine the medium that produced the best results. The evaluation scale used the numbers 0 through 4 to rank the explants, 0 being dead or completely contaminated, 1 having no callus and small $(<0.5 \mathrm{~cm})$ shoots, 2 having some callus and shoot growth (at least 1 shoot $>0.5 \mathrm{~cm}$ ), 3 having callus and shoot proliferation (more than 1 shoot, leaves starting to expand), and 4 having callus and shoot proliferation (more than 1 shoot with expanded leaves). The entire experiment was repeated in February 2002 (experiment 2).

As a result of the rapidity of germination, environmental scanning electron microscope (ESEM) photographs were taken to show the effects of the sterilization treatments (control, 30 minutes in sulfuric acid, and sulfuric acid plus $30 \mathrm{~min}$ in $1.6 \%$ sodium hypochlorite solution) on the seedcoat. Seed preparation for the procedure was not necessary so seeds were viewed in their natural state. Photographic procedures were conducted at the Microscopy and Imaging Center at Texas A\&M University in College Station.

Statistical analysis of data for shoot quality was analyzed using the Wilcoxon Scores (Rank Sums) Test in SAS Systems for Windows, Release 6.12 (SAS Institute Inc., Cary, N.C.). Chi-square was determined using the KruskalWallis test. The binary (yes/no) contamination, survival, and callus data for shoot formation were analyzed using the chi-square option in the FREQ Procedure in SAS Systems for Windows, Release 6.12 (SAS Institute Inc., Cary, N.C.).

Tissue culture and in vitro rooting. Shoot explants were transferred to MS medium containing $15 \mu \mathrm{M}$ zeatin (best growth in shoot proliferation experiment), agar $\left(6 \mathrm{~g} \cdot \mathrm{L}^{-1}\right)$ and sucrose $\left(30 \mathrm{~g} \cdot \mathrm{L}^{-1}\right)$ in test tubes $(15 \mathrm{~mL}$ per tube) for shoot proliferation on 2 Nov. 2003 and sub-cultured on 17 Dec. 2003. Cultures were grown under 12-h photoperiods from fluorescent lighting at $31 \mu \mathrm{mol} \cdot \mathrm{m}^{-2} \cdot \mathrm{s}^{-1}$ measured at bench height.

Shoot apices of the explants were transferred on 1 Feb. 2004 to a half-strength MS basal medium containing the growth regulator indole-3-butyric acid (IBA) (Sigma Chemical Co., St. Louis, Mo.) at concentrations of 0,4 , 12 , or $25 \mu \mathrm{M}$ for the rooting study. Twenty replications per treatment were used (i.e., 20 shoots per treatment). Shoots were uniform in length (1 to $2 \mathrm{~cm})$. Treatments were destructively harvested on 23 Apr. 2004.

A completely randomized design was used. Statistical analysis of data was performed using the general linear models procedure in SAS Systems for Windows, Release 6.12 (SAS Institute Inc., Cary, N.C.) to determine whether there were effects of auxin concentrations for number of roots regenerated, total root length, and average root length per cutting, leaf number, shoot length, and total dry weight $(7 \mathrm{~d}$ at $70{ }^{\circ} \mathrm{C}$ ). Statistical analysis of data for shoots rooted was analyzed using the Wilcoxon Scores (rank sums) test. Chi-square was determined using the Kruskal-Wallis test.

\section{Results and Discussion}

Maintenance of spineless trait from seeds. Germination of mechanically scarified seed was variable among selections. Germination percentages for the three selections in 1999 were $33 \%(\mathrm{~A}), 94 \%(\mathrm{~B})$, and $58 \%(\mathrm{C})$ and in 2001 were $50 \%(\mathrm{~A}), 83 \%(\mathrm{~B})$, and $60 \%(\mathrm{C})$. Clemens et al. (1977) reported variability in 
germination percentages among $A$. falcata Willd. (89\%), A. longifolia (Andr.)Willd. (97\%), A. suaveolens Willd. (77\%), A. terminalis (Salisb.) Macbr. (38\%), and A. myrtifolia (Sm.) Willd. (67\%) $8 \mathrm{~d}$ after manual scarification.

In 1999, 7 months after seedlings were transplanted into 2.1 -L containers $30 \%, 38 \%$, and $14 \%$ of selections A, B, and C, respectively, had maintained the desired spineless trait. At 10 months only $9 \%$ (A), $13 \%$ (B), and 5\% (C) remained spineless. In the second experiment in $2001,0 \%$ (A), $26 \%$ (B), and $34 \%$ (C) were spineless at time of transfer from the germination flats. Expression of the desired spineless trait in $A$. wrightii seedlings was variable. Seedlings were considered spineless only if there were no spines observed. The remaining seedlings varied from spiny to exhibiting very few spines $(<5)$. Instability of traits with seed propagated Acacia for other characteristics has been reported. The Australian Cultivar Registration Authority (ACRA) (2003) reported that A. baileyana F. Muell. 'Purpurea' propagated from seeds results in varying degrees and length of new colored purple growth.

The Federal Seed Act (1940, as revised 1998) does not regulate germination percentages of any tree seed in the U.S. (K. Book, U.S. Dept. of Agriculture, personal communication, April 2003). Thus, whether these germination rates are commercially viable depends on the yield of spineless phenotypes and individual nursery production costs. However, the number of germinated seedlings that retained the desired spineless trait was low.

Sulfuric acid and mechanical scarification. Total germination percentages for seeds from
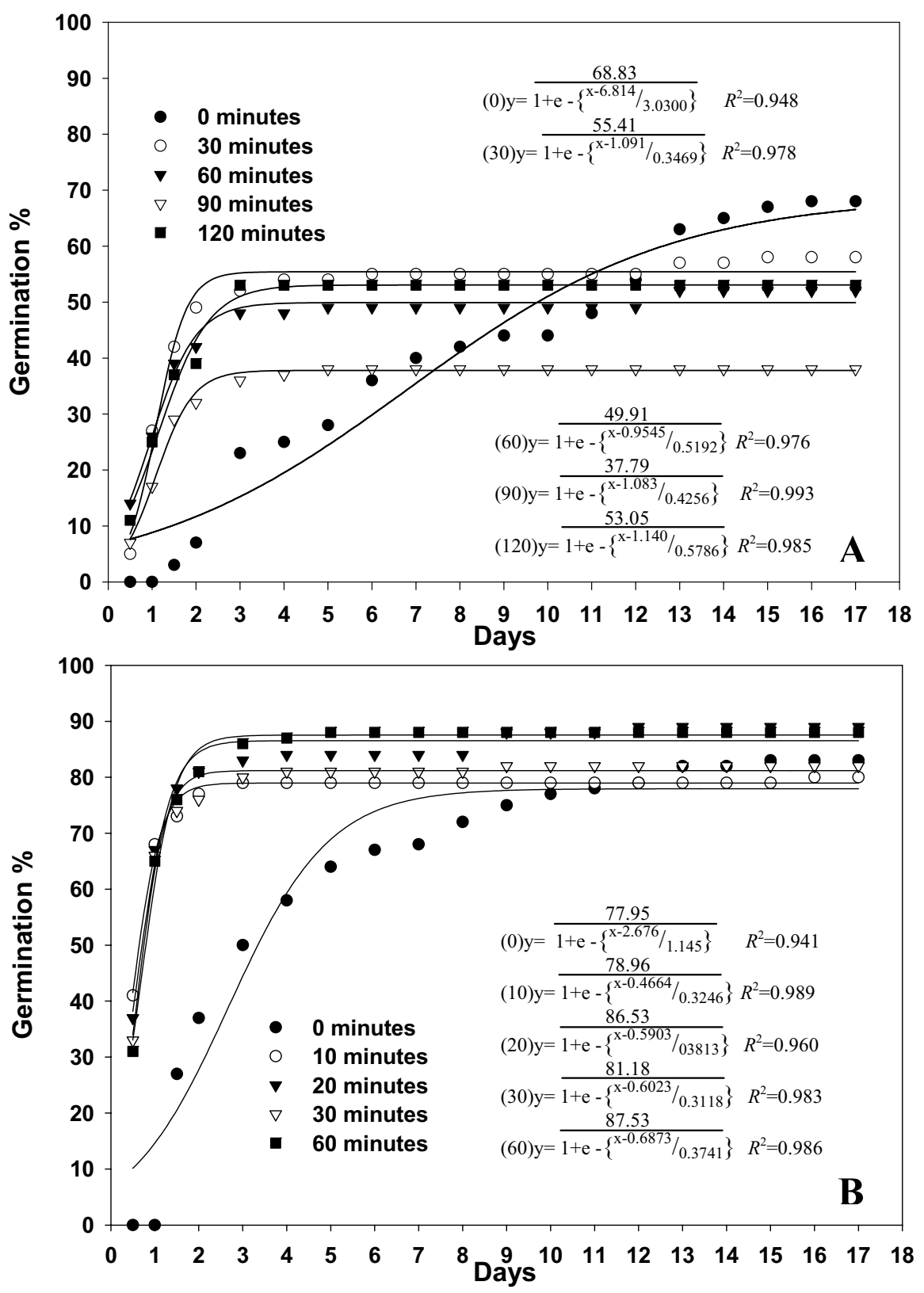

Fig. 1. Cumulative germination percentages for Acacia wrightii seeds treated in concentrated sulfuric acid for $0,30,60,90$, or $120 \min (\mathbf{A}), \mathrm{SE}=5.01, P \leq 0.0001)$ or $0,10,20,30$, or $60 \min (\mathbf{B}), \mathrm{SE}=4.88, P$ $\leq 0.0001)$. Data were collected every $12 \mathrm{~h}$ for $2 \mathrm{~d}$ and once a day for the remaining $17 \mathrm{~d}$. selection $\mathrm{C}$ treated with sulfuric acid (summer 2002 ) were $68 \%$ ( $0 \mathrm{~min}$ ), $58 \%$ (30 $\mathrm{min}), 52 \%$ (60 $\mathrm{min}), 38 \%$ (90 $\mathrm{min})$, and 53\% (120 $\mathrm{min})$ (Fig. 1A). Total germination percentages indicate that sulfuric acid had a negative impact on seed germination. Conversely, the amount of time it took seeds to germinate was reduced by sulfuric acid treatment. Percent germination at day 2 was $7 \%$ ( $0 \mathrm{~min}), 49 \%$ (30 $\mathrm{min})$, $42 \%$ (60 $\mathrm{min}), 32 \%$ (90 $\mathrm{min})$, and $39 \%$ (120 min) (Fig. 1A).

Asecond experiment used shorter durations of acid exposure. Total germination percentages for seeds treated with sulfuric acid in the second experiment were $83 \%$ ( $0 \mathrm{~min}), 80 \%$ (10 $\mathrm{min}$ ), 89\% (20 $\mathrm{min}), 82 \%$ (30 $\mathrm{min}$ ), and $88 \%$ (60 min) (Fig. 1B). Sulfuric acid did not affect total germination in this experiment. The amount of time it took the seeds to germinate, however, was reduced by sulfuric acid treatment. Percent germination at day 2 was $37 \%$ (0 min), 77\% (10 min), 81\% (20 min), 76\% (30 $\mathrm{min})$, and $81 \%$ (60 min) (Fig. 1B). It took 9 to $10 \mathrm{~d}$ before cumulative germination of nontreated seeds was similar to the seeds that were scarified.

Studies report that Acacia spp. varied in scarification time requirements (min) in sulfuric acid to achieve maximum germination; A. planifrons Wight \& Am. (25 min, 88.9\%) (Natarajan and Vinaya Rai, 1986), A. auriculiformis A. Cunn. ex Benth. (30 min, 97\%), A. nilotica (L.) Delile (30 min, 100\%) (Sur et al., 1987), A. tortilis Hayne (50 min, 77.7\%) (Pathak et al., 1980), A. cyanophylla Lindl. (90 min, 98.5\%) (Shaybany, 1976), and $A$. farnesiana (L.) Willd. (120 min, 100\%) (Rana and Nautiyal, 1989).

Mechanical treatment in our first experiment hastened germination ( $46 \%$ at day 2$)$ and improved overall total germination $(87 \%)$ compared to the nontreated control ( $7 \%$ at day 2, 68\% total) (Fig. 2A). Mechanical treatment in our second experiment hastened germination $(47 \%$ at day 2$)$ compared to the control ( $37 \%$ at day 2 ), but did not improve overall total germination $(83 \%$ for both mechanical and control) (Fig. 2B).

Rana and Nautiyal (1989) achieved greater germination of $A$. farnesiana using mechanical scarification by puncturing the micropylar end of seeds with a sharp needle $(90 \%)$ and rubbing the seedcoat with sandpaper (100\%) compared to germination $(0 \%)$ of nontreated seeds. Gill et al. (1986) had similar results when comparing germination percentages with mechanical scarification of $A$. farnesiana using sandpaper $(98 \%)$ to nontreated seeds $(30 \%)$. Lack of improvement in total germination by mechanical scarification may be a species dependent response. Clemens et al. (1977) stated that differences in seed germination exist both among species of Acacia and among different seed treatments used (i.e., hot water, acid scarification, mechanical scarification, etc.). Furthermore the difference in methodology between experiments may contribute to differences in results reported, for example seeds germinated in water agar in growth chambers are provided with optimal environmental conditions, whereas seeds germinated 
in substrate under greenhouse conditions face a more challenging environment.

Propagation of cuttings. There was a significant interaction between cutting maturity and auxin concentration with number of roots per cutting $(P \leq 0.0001)$ and total root length $(P=0.0043)$, but there was no significant interaction for the number of cuttings that rooted $(P=0.0584)$. At the highest auxin concentration $\left(15000 \mathrm{mg} \cdot \mathrm{L}^{-1}\right), 70 \%$ of softwood cuttings rooted (Fig. 3A). Root number of softwood cuttings had a linear response to auxin concentrations, generating as many as nine roots per cutting at $15000 \mathrm{mg} \cdot \mathrm{L}^{-1}$, whereas the control $\left(0 \mathrm{mg} \cdot \mathrm{L}^{-1}\right)$ cuttings had two or fewer roots (Fig 3B). Mean total root length of softwood cuttings also had a linear response to auxin, ranging from an average of
$4 \mathrm{~cm}$ for control cuttings to $12 \mathrm{~cm}$ for those treated with $15000 \mathrm{mg} \cdot \mathrm{L}^{-1}$ auxin (Fig. 3C). While a plateau in root regeneration responses was not reached, the cuttings treated with $15000 \mathrm{mg} \cdot \mathrm{L}^{-1}$ did not regenerate roots from the base of the cutting which was necrotic (roots emerged from higher up the stem). This suggests that concentrations greater than $15000 \mathrm{mg} \cdot \mathrm{L}^{-1}$ would be potentially toxic to the cutting. Ahmad (1991) reported a rooting success of $76 \%$ with softwood cuttings from 1-year-old A. mangium Willd. with application of $500 \mathrm{mg} \cdot \mathrm{L}^{-1}$ IBA compared to $36 \%$ rooting success for the nontreated control.

Rooting of hardwood and semi-hardwood cuttings was low for all auxin concentrations $(<20 \%$ rooted)(Fig. $3 \mathrm{~A})$. Those hardwood and semi-hardwood cuttings that did root, regener-
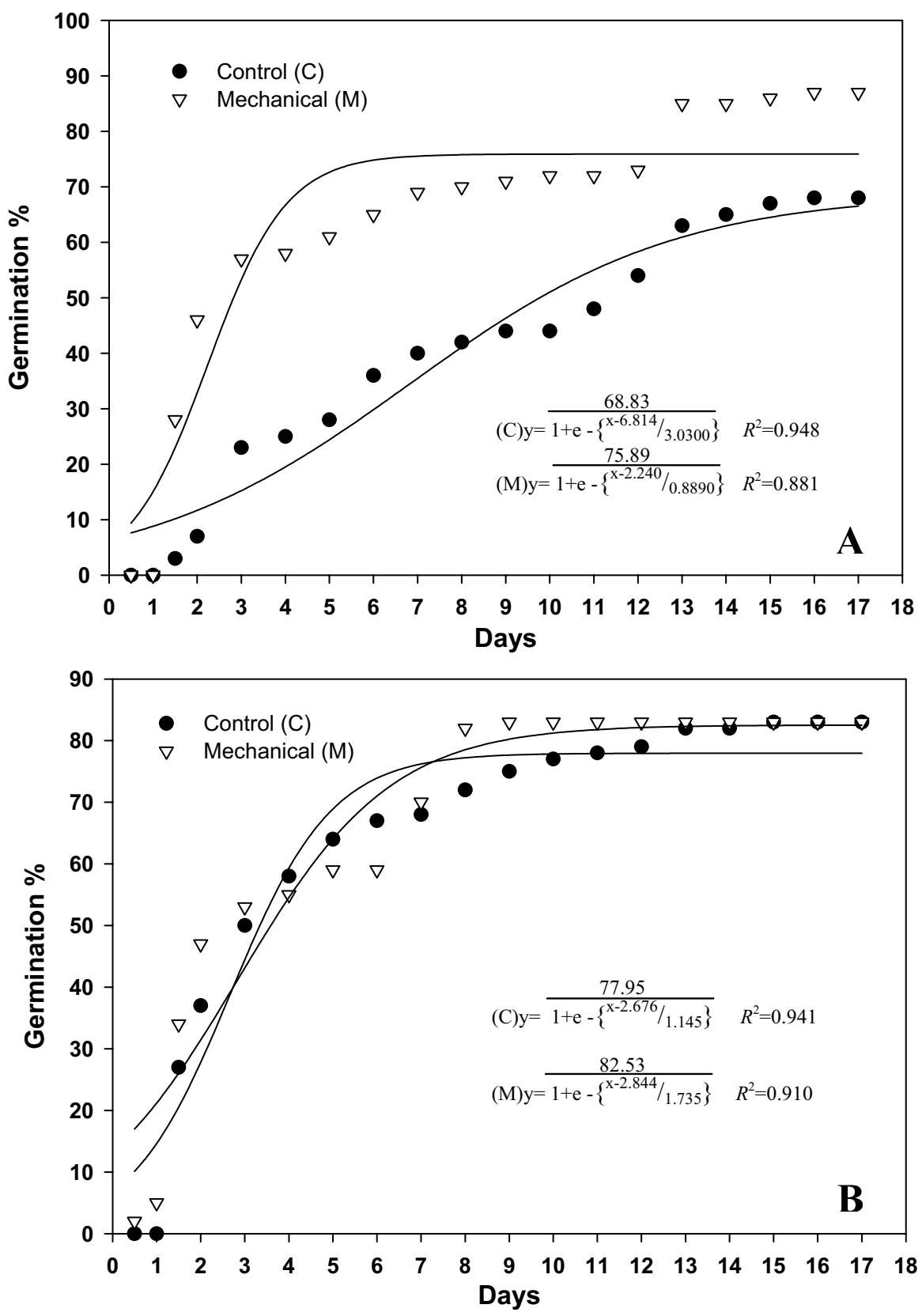

Fig. 2. Comparisons of cumulative germination percentages for mechanically scarified (nicked seedcoat) and control (nontreated) Acacia wrightii seeds [experiment $1 \mathrm{SE}=5.67, P \leq 0.0001$ (A); experiment $2 \mathrm{SE}=$ $4.61, P \leq 0.0001(\mathbf{B})]$. Data were collected every $12 \mathrm{~h}$ for $2 \mathrm{~d}$ and once a day for the remaining $17 \mathrm{~d}$. ated only one root per cutting and total root length per cutting averaged $<2 \mathrm{~cm}$ (Figs. $3 \mathrm{~B}$ and 3C). Schwarz et al. (1999) reported a rooting success of $36 \%$ in semi-hardwood cuttings of A. baileyana with application of $5000 \mathrm{mg} \cdot \mathrm{L}^{-1}$ IBA compared to $4 \%$ rooting success for the control treatment.

Treating softwood cuttings of $A$. wrightii with $15000 \mathrm{mg} \cdot \mathrm{L}^{-1}$ auxin is potentially a commercially viable method for propagating this spineless trait. Cuttings rooted at a high rate and were retaining the spineless phenotype at the time of harvest. Hardwood and semi-hardwood cuttings did not root at a high enough percentage with the treatments tested to be a commercially viable method of production. Ahmad (1991) found that rooting success of A. mangium depended on the age of the stock plant with cuttings from a 6-month-old stock plant rooting at $71.3 \%$ and cuttings from a 2year-old stock plant rooting at $15 \%$. The stock plants used in this study (2001) were about 7 years old (seed planted in Fall 1994).

Grafting. In France and Italy grafting (T-budding and approach grafting) is used for the propagation of Acacia spp. grown for cut-flower production (Johnson and Burchett, 1996). However, none of the three grafting procedures attempted, whip-and-tongue, T-budding, and whip-and-tongue with auxin, formed a viable union between rootstock and scion. Color and condition of the grafts suggested possible production of large concentrations of phenolic compounds, which may have damaged surrounding tissue and impaired callus formation. Excessive production of phenolics has been reported as a problem during in vitro regeneration of Acacia spp. (Vengadesan et al., 2002).

Tissue culture. Sterile cultures of $A$. wrightii were established using sulfuric acid and bleach treatments (Douglas, 1995). Seeds were not adversely affected by the sulfuric acid and bleach treatments, in fact germination was extremely rapid and uniform. Environmental scanning electron micrograph (ESEM) photos show an intact impenetrable seedcoat from the control treatment(Fig. 4A). The intact seedcoat may act as a barrier to water, oxygen and the exchange of other gases and slows germination. Pits are visible in the seedcoat after being treated with sulfuric acid (Fig. 4B). These pits may speed germination by enhancing the imbibition of water, oxygen and the exchange of other gases. The seedcoat was loosened sufficiently during the bleach treatment to facilitate its removal, thus exposing the seed and removing all physical barriers (Fig. 4C).

The best $(P \leq 0.01)$ shoot proliferation with mean score of 96.5 by Wilcoxon rank scores test for both replications combined was on MS $15 \mu \mathrm{M} \mathrm{Z}$ medium (Table 1). Shoot proliferation from in vitro germinated seedlings in this study was better on MS than WPM. Vengadesan et al. (2002) reported that MS medium was preferred to WPM for many Acacia spp., for example $A$. salicina Lindl., $A$. saligna (Labill.) H.L. Wendl., A. sclerosperma F. Muell. (Jones, 1990), A. mangium (Bhaskar and Subhash, 1996; Galiana et al., 1991), $A$. catechu (L.f.) Willd. (Kaur et al., 1998), $A$. 
albida Delile. (Ruredzo and Hanson, 1993), A. mearnsii DeWilld. (Huang et al., 1994), and $A$. sinuata (Lour.) Merr. (Vengadesan et al., 2000).

The number of shoots that rooted was significant (chi square $P \leq 0.05$ ) with an increase in rooting mean scores (Wilcoxon rank scores test) with increasing concentration of auxin (IBA). Mean scores were 16.5, 20.3, 26.7, and 28.8 for $0,4,12$, and $25 \mu \mathrm{M}$ IBA, respectively. There was no significance in any of the other root or shoot growth parameters (root number per cutting, total root length, average root length, shoot length, leaf number, or total dry weight). Kaur and Kant (1999) reported the best rooting of $A$. catech $u$ shoots on quarter-strength MS media with $3 \mathrm{mg} \cdot \mathrm{L}^{-1}(17.1 \mathrm{mM})$ IAA. Vengadesan et al. $(2000,2002)$ reported the best root growth on $A$. sinuata using half-strength MS medium with $1.75 \mu \mathrm{M}$ IBA. This study demonstrates that $A$. wrightii can be proliferated and rooted in vitro from germinated seedlings of the spineless selection. There is potential to select for the spineless phenotype from among these tissue cultured genotypes.

In conclusion, mechanical scarification of $A$. wrightii seeds (selections A, B, and C) was effective for selections $\mathrm{B}$ and $\mathrm{C}$, however, the number of germinated seedlings which retained the desired spineless trait was low. Sulfuric acid treatment of 20 to $30 \mathrm{~min}$ hastened and unified germination of $A$. wrightii seeds (selection C). Mechanical scarification (selection $\mathrm{C}$ ) was as effective as chemical scarification in total germination, however, it was not as effective in unifying germination. Acacia wrightii softwood cuttings had a higher rooting percentage, more roots regenerated per cutting, and longer total root lengths than either semi-hardwood or hardwood cuttings when treated with 15000 $\mathrm{mg} \cdot \mathrm{L}^{-1}\left(10000 \mathrm{mg} \cdot \mathrm{L}^{-1} \mathrm{IBA}\right.$ and $\left.5000 \mathrm{mg} \cdot \mathrm{L}^{-1} \mathrm{NAA}\right)$ auxin. In this study, grafting was not an effective approach for propagation of this selection of $A$. wrightii with the techniques used. Tissue culture studies indicated $A$. wrightii shoot proliferation was greatest at $15 \mu \mathrm{M} \mathrm{Z}$ and in vitro rooting was best at $25 \mu \mathrm{M}$ IBA. Further experimentation is necessary to determine an acclimatization strategy.
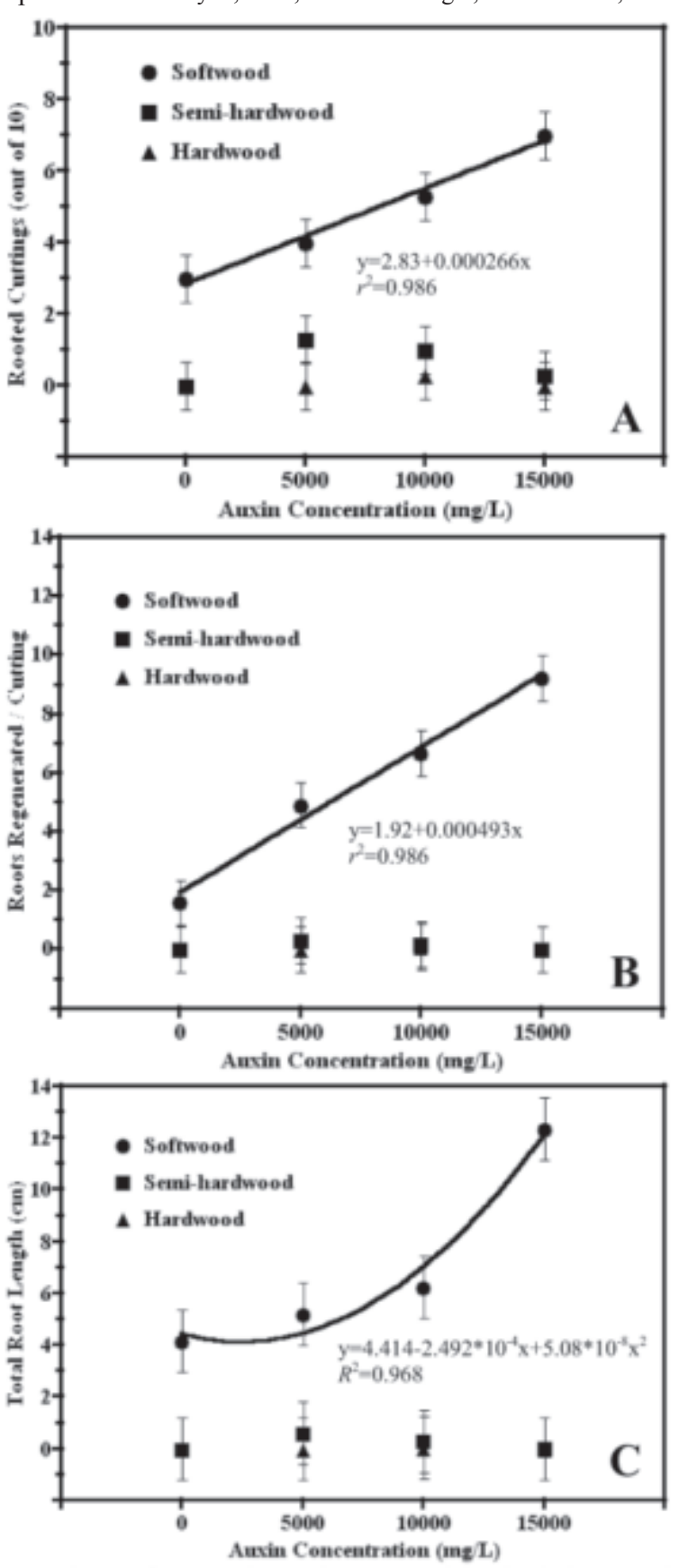

Fig. 3. Mean $( \pm$ SE) number of rooted cuttings per block (A), number of roots regenerated per cutting $(\mathbf{B})$, and total root length per cutting $(\mathbf{C})$ of softwood $(\mathbf{O})$, semi-hardwood $(\mathbf{\square})$, and hardwood $(\mathbf{\Delta})$ cuttings of Acacia wrightii in response to increasing concentrations of auxin (2 IBA: 1 NAA). Regression equations are provided where significant, $P=0.0584$ (A), $P \leq 0.0001$ (B), and $P=0.0043(\mathbf{C})$.
Hall, and M.A. Arnold. 2002. Propagation of spineless wright acacias. Proc. SNA Res. Conf. 47:306-311.

Clemens, J., P.G. Jones, and N.H. Gilbert. 1977. Effect of seed treatments on germination in Acacia. Austral. J. Bot. 25:269-276.

Douglas, G. 1995. Micropropagation, p. 38-56. In: K. Lamb, J. Kelly, and P. Bowbrick (eds.). Nursery stock manual. Grower Books, Nexus Media Limited, Swanley, Kent.

Galiana, A., A. Tibok, and E. Duhoux. 1991. In vitro propagation of the nitrogen fixing tree legume Acacia mangium Willd. Plant Soil 135:151-159.

Garner, R.J. 1993. The grafter's handbook, 5th ed.
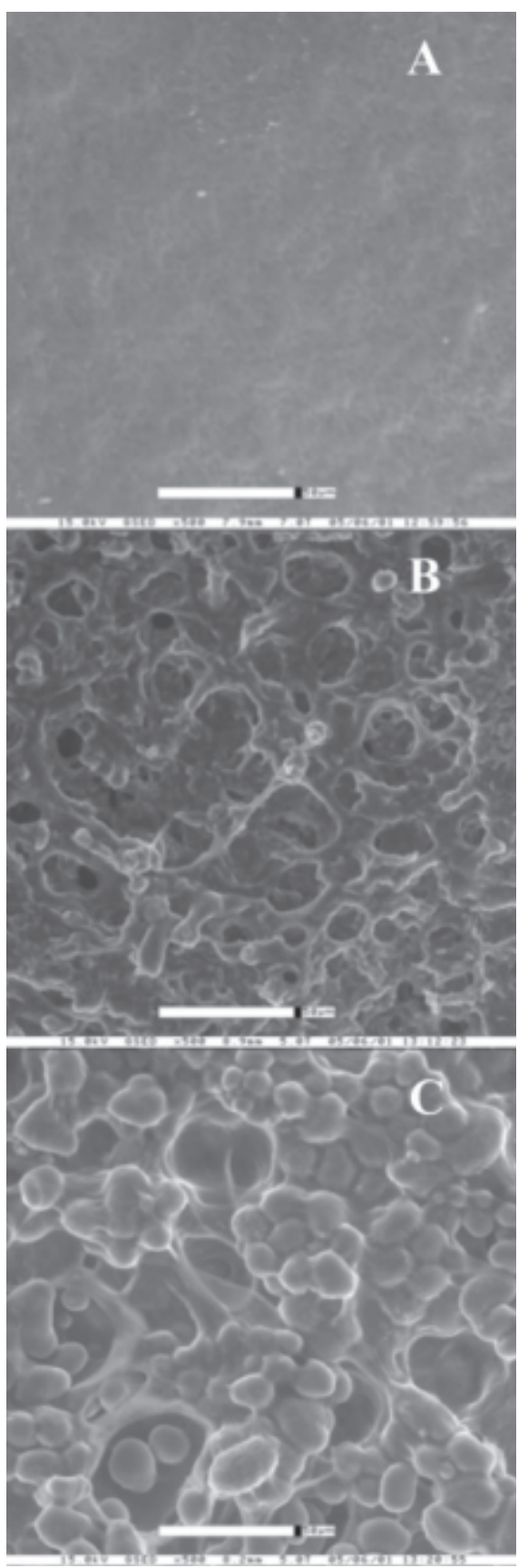

Fig. 4. Environmental scanning electron micrograph of Acacia wrightii seeds. Control nontreated seedcoat (A). Seedcoat after $30 \mathrm{~min}$ in concentrated sulfuric acid (B). Seed after $30 \mathrm{~min}$ in concentrated sulfuric acid followed by 30 min in $1.6 \%$ sodium hypochlorite solution (seedcoat peeled off exposing the cotyledon surface) $(\mathbf{C})$.

HortScience Vol. 40(6) October 2005 
Table 1. Effect of Murashige and Skoog (MS) or Woody Plant Medium (WPM) on in vitro Acacia wrightii shoot proliferation quality ${ }^{\mathrm{x}}$ in response to increasing concentrations $(0,5,10,15$, or $20 \mathrm{mM})$ of benzyladenine or zeatin.

\begin{tabular}{lcccc}
\hline $\begin{array}{l}\text { Concn } \\
(\mathrm{mM})\end{array}$ & $\begin{array}{c}\text { MS } \\
\text { benzyladenine }\end{array}$ & $\begin{array}{c}\text { MS } \\
\text { Zeatin }\end{array}$ & $\begin{array}{c}\text { WPM } \\
\text { benzyladenine }\end{array}$ & $\begin{array}{c}\text { WPM } \\
\text { zeatin }\end{array}$ \\
\hline 0 & $76.1^{\mathrm{y}}$ & 63.2 & 78.9 & 70.3 \\
5 & 74.9 & 67.7 & 85.7 & 83.0 \\
10 & 72.3 & 90.1 & 73.9 & 96.3 \\
15 & 79.5 & 96.5 & 68.0 & 69.4 \\
20 & 99.5 & 83.0 & 96.0 & 83.4 \\
Significance & & $* *$ & $*$ & NS \\
Chi-square & NS & $*$ & $*$
\end{tabular}

${ }^{\mathrm{x}}$ Shoots were qualitatively ranked. $0=$ dead and/or completely contaminated to $4=$ having callus and expanded shoots.

${ }^{\mathrm{y}}$ Mean scores by Wilcoxon Scores (rank sums) test, $\mathrm{n}=32$.

NS,",**N Nonsignificant or significant at $P \leq 0.05$, and 0.01 , respectively, using Kruskal-Wallis test, $\mathrm{n}=32$.

Cassell Publ. Limited, London, U.K.

Gill, L.S, R.O. Jagede, and S.H. Husaini. 1986. Studies on the seed germination of Acacia farnesiana (L.) Wild. J. Tree Sci. 5(2):92-97.

Huang, F.H., J.M. Al-Khayri, and E. Gbur. 1994. Micropropagation of Acacia mearnsii. In Vitro Cell Dev. Biol. Plant. 30:70-74.

Johnson, K.A. and M. Burchett. 1996. Native Australian plants horticulture and uses. University of New South Wales Press. Sydney, Australia.

Jones, T.C., C.A. Batchelor, and P.J.C. Harris. 1990. In vitro culture and propagation of Acacia species (A. bivenosa, A. holosericea, A. salicina, A. saligna and $A$. sclerosperma). Intl. Tree Crops J. 6:183-192.

Kaur, K. and U. Kant. 1999. Callus formation and plantlet regeneration from cell suspension cultures of Acacia catechu Willd. Indian J. Expt. Biol. 37:609-611.
Natarajan, N. and R.S. Vinaya Rai. 1986. Studies on seed scarification in Acacia planifrons. Van Vigyan 24:80-82.

Nokes, J. 2001. How to grow native plants of Texas and the southwest, revised and updated ed. Univ. of Texas Press, Austin.

Pathak, P., S. Gupta, and R. Deb Roy. 1980. Studies on seed polymorphism, germination, and seedling growth of Acacia tortilis Hayne. Indian J. For. 3(1):64-67.

Rana, U. and A. Nautiyal. 1989. Coat imposed dormancy in Acacia farnesiana seeds. Seed Res. 17(2):122-127.

Ruedzo, T.J. and J. Hanson. 1993. Plant recovery from seedling derived shoot tips of Faidherbia albida grown in vitro. Agroforestry Systems 22:59-65.

Schwarz, J.L., P.L. Glocke, and M. Sedgley. 1999. Adventitious root formation in Acacia baileyana F. Muell. J. Hort. Sci. Biotechnol. 74:561-565.

Shaybany, B. 1976. Effect of pre-sowing treatments and temperatures on seed germination of Acacia cyanophylla Lindl. HortScience 11:381-383.

Sur, K., A.K. Lahiri, and R.N. Basu. 1987. Improvement of germinability of some forest tree seeds by acid scarification and hydration-dehydration treatments. Indian Agr. 31(2):115-122.

Vengadesan G., A. Ganapathi, S. Amutha, and N. Selvaraj. 2002. In vitro propagation of Acacia species-A review. Plant Sci. 163:663-671.

Vengadesan G., A. Ganapathi, R.P. Anand, and V.R. Anbazhagan. 2000. In vitro organogenesis and plant formation in Acacia sinuata. Plant Cell Tissue Organ Cult. 6:23-28. 